\title{
A survey of housing equity withdrawal and injection in Australia
}

\author{
Carl Schwartz, Tim Hampton, Christine Lewis and David Norman ${ }^{2}$
}

\section{Introduction}

Over recent years in Australia, housing-secured debt has increased by more than household spending on new housing, renovations and housing transfer costs. As a result, the household sector has extracted equity from the housing stock, in contrast to the experience of previous decades (Figure 1). The move from a situation of net equity injection to one of net equity withdrawal has coincided with strong household consumption growth and a decline in the household saving rate. A similar phenomenon has been experienced in many other countries.

Figure 1

\section{Housing equity withdrawal}

Four-quarter moving average

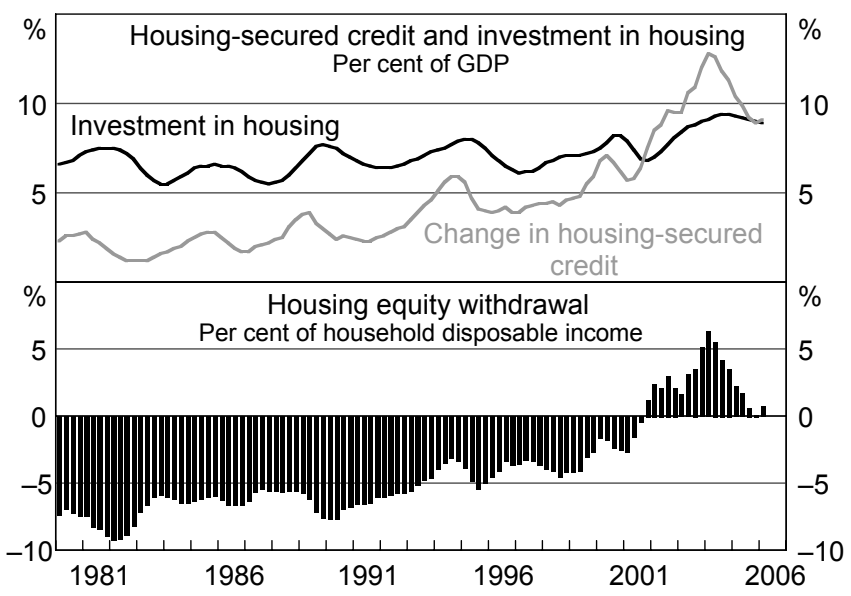

Sources: ABS; APM; Australian Treasury; RBA

The trend towards housing equity withdrawal in Australia over the past 15 years or so reflects fundamental changes to both the demand and supply side of housing finance. Lower nominal interest rates associated with lower inflation have allowed households to take on larger debts, and the relative stability of interest rates and the economy have given households greater confidence that they can service larger debt burdens. Competition among intermediaries has further driven down interest rates on housing loans and increased households' ability to access equity using more flexible mortgage products. These

\footnotetext{
1 This paper was prepared for the Irving Fisher Committee Conference on Measuring the Financial Position of the Household Sector, Basel, August 30-31, 2006, and is based on Schwartz et al (2006). The views expressed in the paper do not necessarily reflect those of the Reserve Bank.
}

2 Reserve Bank of Australia (RBA). 
developments have been associated with strong growth in house prices, which has increased the amount of equity accessible by property owners. ${ }^{3}$

While we can identify macroeconomic factors conducive to housing equity withdrawal in Australia, little is known about the household behaviour underpinning it. Given this lack of information, the Reserve Bank of Australia commissioned a survey to better understand how households were withdrawing and injecting housing equity, the characteristics of households engaging in these activities, and how the withdrawn funds were used. The survey covered flows over 2004 associated with housing debt, housing transactions, and renovation spending. In addition to being the first of its kind in Australia, this comprehensive survey represents an important extension to the more narrowly focused international literature on this topic. ${ }^{4}$

\section{Concepts and survey design}

\section{$2.1 \quad$ Concepts}

Housing equity withdrawal and injection refer to the net cash flow by households from transactions in housing-secured debt and housing assets. Withdrawals and injections can occur in many different ways. One way for a household to withdraw housing equity is to increase the level of debt secured against a property they already own through methods such as refinancing and increasing the size of the loan, or drawing down a home-equity style loan. Another is by reducing property holdings (for example, by downsizing). ${ }^{5}$ Households can inject equity into a property they already own by paying down housing debt or undertaking renovations financed, at least partly, from their own funds. Households increasing their property holdings often also inject equity through a deposit.

There are many factors potentially underlying a household's flow of housing equity, including their preferences regarding:

- $\quad$ consumption and saving, such as a desire to smooth consumption over a life-time or in response to temporary changes in income;

- $\quad$ financial management, such as asset diversification (by using accumulated housing equity to purchase other non-housing assets), replacing higher interest-rate personal debt with housing-secured debt, or using surplus funds to either pay down housing debt or invest in property; and

- $\quad$ living arrangements, often associated with their stage of life (for example, an elderly household selling a long-held owner-occupied property to move into a retirement home is likely to withdraw equity, while a first-home buyer will typically inject equity).

3 These fundamental changes have been discussed at length in many Reserve Bank of Australia publications and elsewhere. See, for example, Reserve Bank of Australia (2002a) and (2002b).

4 Surveys of mortgage holders were carried out in the US (Canner, Dynan and Passmore 2002) and Netherlands (de Nederlandsche Bank 2000; van Els, van den End and van Rooij 2005). Two English surveys extended these to include some transactions (Davey and Earley 2001; Benito and Power 2004) but these still did not capture last-time sales.

5 The household sector as a whole typically does not withdraw equity in this way since it implies sales to other sectors of the economy or non-residents. 


\subsection{Design}

The Bank's survey of Australian households builds on earlier international surveys in several important respects. This survey focuses on net injection or withdrawal over the course of a calendar year, rather than being event-based. This approach ensures coverage of injections as a result of regular or lump-sum principal repayments - important forms of injection not captured by earlier international surveys. Other forms of injection, including renovations, are also dealt with more comprehensively by capturing renovations that were financed without debt. In another advance, the survey asked respondents about inherited residential property and funds received from the sale of inherited property. This is necessary because sales of deceased estates result in an equity withdrawal, which otherwise would not be captured. The survey also collected information on the features of each household's mortgage, to assist in gauging the importance of financial innovations to housing equity flows.

The Bank engaged an external company, Roy Morgan Research, to assist in questionnaire design and conduct the survey. The results in this paper are based on 4500 respondent households, interviewed by telephone in February 2005.

The myriad of ways in which households can withdraw or inject housing equity required a questionnaire with different paths depending on the behaviour of the household. At its core, the questionnaire asked for data relating to changes in housing-secured debt and housingrelated transactions over 2004. Respondents were asked about the characteristics of their property holdings, followed by questions to determine how their housing equity had changed over 2004. From these responses, it was possible to determine whether the household was a net withdrawer, injector or neither. Finally, there were questions about the use of funds by withdrawers and source of funds for injectors.

\subsection{Calculating equity withdrawal and injection}

Over a given period, households may undertake a number of housing equity withdrawals and injections or take no such actions at all. For the purpose of analysis, households were divided into withdrawers and injectors on the basis of the net result of their actions over 2004. That is, over 2004, a household made a net equity withdrawal if the change in housing debt minus the change in housing equity from property transactions (including inheritances flowing from the sale of property) minus renovation expenditure was greater than zero. Similarly, a household made a net equity injection if this calculation was less than zero. These calculations are described in further detail in Appendix A.

In analysing the results, households identified as having withdrawn or injected net equity over 2004 were classified into a further two broad sub-groups: transactors in the property market, and non-transactors.

The group of households that undertook property transactions includes: households that reduced their property holdings; households that increased their property holdings, often as a first-home buyer or an investor; and those that were both buyers and sellers. For the bulk of this group, the housing equity flows associated with their transactions were the main drivers of whether they made a net withdrawal or injection over 2004.

Non-transacting property owners that injected equity did so by paying down principal on existing debt or through renovations financed, at least partly, from their own funds. Those that withdrew equity increased housing-secured debt, via methods such as refinancing or drawing down a home-equity style loan. Households that withdrew in this way included some renovators, where the increase in housing-secured debt exceeded the amount spent on renovations. 


\section{How was equity withdrawn and injected?}

According to the survey, 42 per cent of households changed their housing equity over 2004; 12 per cent of households made a net withdrawal of equity over 2004, while 30 per cent made a net injection (Table 1). The remaining households neither withdrew nor injected equity, largely because they did not own any property, or owned their property outright.

By number, the bulk of households changing housing equity were non-transactors - 33 per cent of households versus 9 per cent that were property transactors. Around $71 / 4$ per cent of households made a net equity withdrawal by increasing debt on their existing property; for these households, the median increase in debt over the year was A\$20 000, while the mean was considerably larger. A much larger number of households injected equity into their existing property, with 19 per cent of all households injecting equity through scheduled and additional payments on their housing loans, and a further $61 / 2$ per cent injecting equity through renovations. The median value of injections by non-transactors was considerably smaller than the median withdrawal made by non-transactors.

Table 1

How equity was withdrawn and injected

\begin{tabular}{l|c|c|c}
\hline & $\begin{array}{c}\text { Share of all } \\
\text { households } \\
\text { (per cent) }\end{array}$ & $\begin{array}{c}\text { Median value } \\
\text { (A\$) }\end{array}$ & $\begin{array}{c}\text { Mean } \\
\text { value } \\
\text { (A\$) }\end{array}$ \\
\hline $\begin{array}{l}\text { Non-transactors in } \\
\text { property }\end{array}$ & $\mathbf{3 2 . 8}$ & $\mathbf{6 0 0 0}$ & $\mathbf{9 4 0 0}$ \\
$\begin{array}{l}\text { Withdrawal of equity } \\
\text { by increasing debt }\end{array}$ & 7.3 & -20000 & -36700 \\
$\begin{array}{l}\text { Injection of equity by: } \\
\text { Paying down debt }\end{array}$ & 19.0 & 9000 & 19500 \\
$\quad$ Renovating & 6.5 & 14000 & 31800 \\
& 9.0 & $\mathbf{1 4 0 0}$ & -15100 \\
Property transactors & 4.4 & -82700 & -159100 \\
Withdrawing equity & 4.6 & 55100 & 122200 \\
Injecting equity & & & \\
\hline
\end{tabular}

Source: RBA.

The finding that 9 per cent of households were involved in at least one property transaction in 2004 is broadly consistent with the available housing turnover data. These households were almost equally split between those withdrawing and injecting equity. However, the median change in equity resulting from these transactions was considerably larger than for nontransactors, such that property transactions contributed the bulk of the value of gross injections and withdrawals.

\subsection{Withdrawals}

Almost three quarters of the value of all (net) withdrawals by households that were net withdrawers over 2004 were accounted for by those that engaged in property transactions (Table 2). Of the net withdrawals by property transactors, around three quarters of the value was accounted for by the 2.7 per cent of households that sold more properties than they 
bought. This large contribution in part reflects the larger median withdrawal by such households - A\$125900 versus A\$33 500 for withdrawals based on other combinations of property transactions. These other property transactions were fewer in number and smaller in value, but nonetheless remained significant as a share of overall withdrawn equity accounting for almost one fifth of the total value withdrawn.

Table 2

\section{Housing equity withdrawal by method}

\begin{tabular}{l|c|c|c}
\hline & $\begin{array}{c}\text { Share of all } \\
\text { households } \\
\text { (per cent) }\end{array}$ & $\begin{array}{c}\text { Median } \\
\text { value } \\
\text { (A\$) }\end{array}$ & $\begin{array}{c}\text { Share of } \\
\text { value } \\
\text { withdrawn } \\
\text { (per cent) }\end{array}$ \\
\hline Non-transactors in property & $\mathbf{7 . 3}$ & $\mathbf{2 0 0 0 0}$ & $\mathbf{2 7 . 9}$ \\
Refinancing and new loans & 4.5 & 28000 & 20.3 \\
Redraw facilities & 1.4 & 11000 & 3.0 \\
Revolving credit & 0.7 & 20000 & 3.4 \\
Withdrawal from offset account & 0.3 & 8000 & 0.6 \\
Cannot say/other & 0.5 & 6000 & 0.6 \\
Property transactors & 4.4 & $\mathbf{8 2 7 0 0}$ & $\mathbf{7 2 . 1}$ \\
Sold more properties than bought & 2.7 & 12590 & 0 \\
Bought more properties than sold & 0.9 & 18300 & 54.1 \\
Bought and sold equal number of properties & 0.8 & 54000 & 10.7 \\
\hline
\end{tabular}

Notes: Components may not sum due to rounding. The "sold more properties than bought" category includes households that sold a property they inherited, and households that received a bequest funded by the sale of a deceased estate.

Source: RBA.

Sales of owner-occupied property - which include last-time sales of elderly households' properties - appear to be associated with larger net equity withdrawals than sales of investment property. This is consistent with the finding that for those that sold more properties than they bought, the median loan-to-valuation ratio (LVR) of owner-occupied properties sold was slightly lower than it was for investment properties (Table 3); this is not surprising given the tax advantages of interest deductibility for investment properties in Australia. ${ }^{6}$ This is despite the fact that the typical investment property had been held for slightly longer than were the owner-occupied properties, allowing more time to accumulate capital gains and pay down debt. Owner-occupied properties also tended to sell for more than investment properties and second homes, consistent with investment property being generally more concentrated in cheaper housing stock such as units.

6 Valuations were provided by the household. However, we believe that our analysis is unlikely to be biased by subjective valuations for the same reasons described in Ellis, Lawson and Roberts-Thomson (2003). In addition, it may be that households' perceptions of their financial position are more relevant to our analysis than is their actual position. 
Table 3

Sales by withdrawers that sold more properties than they bought

\begin{tabular}{l|l|c|c|c}
\hline \multicolumn{1}{c|}{ Variable } & Units & $\begin{array}{c}\text { Owner-occupied } \\
\text { property }\end{array}$ & $\begin{array}{c}\text { Investment } \\
\text { property }\end{array}$ & $\begin{array}{c}\text { Second } \\
\text { home/land }\end{array}$ \\
\hline Share & Per cent & 36.6 & 29.1 & 34.3 \\
Median sale price & A $\$ 274000$ & 5 & 258000 & 160000 \\
Median time held & Years & 110000 & 104000 & 6 \\
Median debt at sale & A & 0.50 & 0.58 & - \\
Median LVR at sale & Ratio & 6 & - \\
\hline
\end{tabular}

Notes: Debt and LVR are only for properties that had debt outstanding at the time of sale. Medians are not reported where sample size is very small.

Source: RBA.

Of the non-transacting households that withdrew equity, by far the most common methods were to refinance an existing loan and increase the outstanding balance or to take out a new loan. ${ }^{7}$ Two other common methods were drawing upon previous excess principal payments or drawing on a revolving or home-equity type facility. Around 20 per cent of non-transactor households that withdrew equity undertook renovations. The methods these renovating households employed to increase their debt were in similar proportions to the overall group, though the median amount these households withdrew was slightly larger at A\$22 500 .

\subsection{Injections}

In contrast to the results for households withdrawing equity, for households that made a net equity injection over 2004, the value of injections was split fairly equally between nontransactors and transactors. This reflected a large number of non-transacting households making small injections by paying down debt or renovating, balanced by a small number of households making large injections through property transactions (Table 4).

Within the 19 per cent of households that injected equity by reducing debt on their existing property, 9.6 per cent reported that they simply made the regular scheduled repayments, while an additional 6.7 per cent made regular repayments above those required by their lender. A further 2.1 per cent indicated that they made irregular lump-sum repayments. These one-off lump-sum payments tended to be relatively large, so that they accounted for a disproportionately high share of the total equity injected.

Around $6 \frac{1}{2}$ per cent of households injected equity over 2004 through renovations, financed, at least partly, from their own savings. In total, this amounted to around 18 per cent of the total amount of equity injected by households that made a net injection over 2004 .

7 In Australia most loans are at variable interest rates, so that refinancing decisions are less commonly motivated by reducing interest costs than in countries where fixed-rate loans are dominant. 
Table 4

Housing equity injection by method

\begin{tabular}{l|c|c|c}
\hline & $\begin{array}{c}\text { Share of all } \\
\text { households } \\
\text { (per cent) }\end{array}$ & $\begin{array}{c}\text { Median value } \\
\text { (A\$) }\end{array}$ & $\begin{array}{c}\text { Share of value } \\
\text { injected } \\
\text { (per cent) }\end{array}$ \\
\hline Non-transactors in property & $\mathbf{2 5 . 5}$ & $\mathbf{1 0 0 0 0}$ & $\mathbf{5 0 . 7}$ \\
Reducing debt on existing property & 19.0 & 9000 & 32.5 \\
Renovations & 6.5 & 14000 & 18.3 \\
Property transactions & $\mathbf{4 . 6}$ & $\mathbf{5 5 1 0 0}$ & $\mathbf{4 9 . 3}$ \\
Sold more properties than bought & 0.4 & 52400 & 2.0 \\
Bought more properties than sold & 3.6 & 58800 & 41.0 \\
Bought and sold equal number of properties & 0.6 & 35600 & 6.2 \\
\hline
\end{tabular}

Notes: Components may not sum due to rounding. The "sold more properties than bought" category includes households that sold a property they inherited, and households that received a bequest funded by the sale of a deceased estate. Medians are not reported where sample size is very small.

Source: RBA.

Within the 4.6 per cent of households that injected equity and undertook a property transaction, most purchased more properties than they sold, accounting for the bulk of equity injected by property transactors. Over half of the properties purchased by this sub-group were owner-occupied homes, with around 40 per cent these purchased by first-home buyers. The owner-occupier purchases tended to be associated with more expensive properties and lower debt levels compared to those for other properties. These results are consistent with investors' preferences for relatively cheaper property and higher gearing mentioned in Section 3.1.

A comparison of the results regarding the methods of housing equity withdrawal and injection underscores the importance of transactions to overall flows of housing equity withdrawal. In particular, for the groups of property transactors most important for overall housing equity flows - withdrawers that sold more properties than they bought and injectors that bought more properties than they sold - sellers typically withdrew more equity than buyers injected, partly reflecting much higher debt levels among buyers. This is consistent with the influences of life-cycle factors and house price gains discussed in Sections 3 and 6 . It also follows that shifts in the level of aggregate transaction activity will likely be associated with changes in the value of aggregate housing equity withdrawal.

\section{Characteristics of households withdrawing and injecting equity}

Having identified the various methods through which households withdrew and injected equity during 2004, it is of interest to consider whether there are common characteristics across households that withdrew or injected equity.

The survey data confirm that age and income are key variables in distinguishing households that altered their housing equity from the rest of the population. The results are consistent with previous work that show age and income to be important determinants of the incidence 
of home ownership with debt. ${ }^{8}$ They also confirm that households that own property, particularly those with housing debt, are most readily able to withdraw or inject equity.

Figure 2 shows the age profile of households in the survey - where age is determined by that of the household head, defined as the main income earner. Clearly, those aged between 40 and 49 accounted for the highest proportion of households that changed housing equity, and the highest proportion of property owners with housing debt. In comparison, the age profiles for all households and all property owners are much flatter. Also, withdrawers and injectors tended to have higher household incomes than the general population, as did property owners - particularly indebted property owners.

Figure 2

Housing equity actions by age

Per cent of households in each group ${ }^{1}$

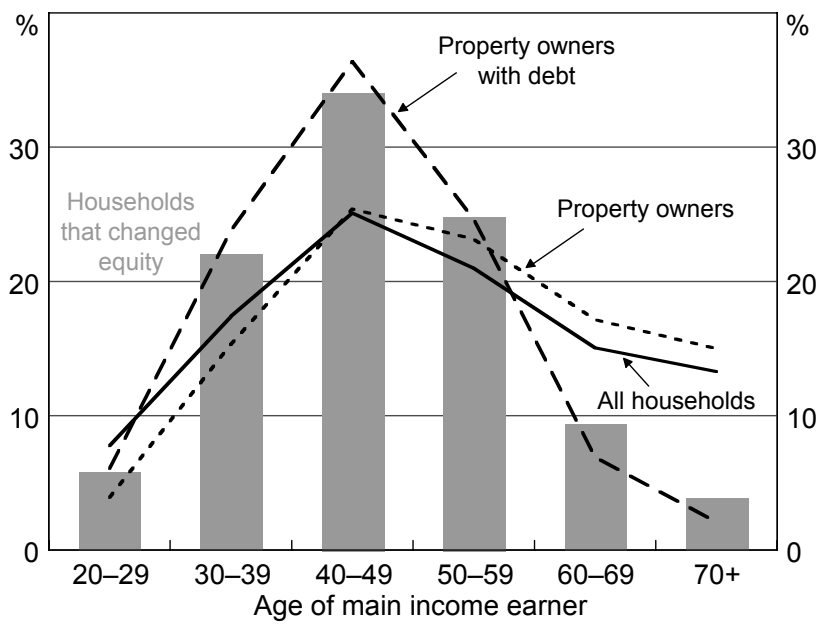

1 Households with main income earner under 20 years not shown.

Source: RBA.

Age also differed notably between households that withdrew equity and those that injected, with withdrawer households typically older. The breakdown of average net housing equity flows from the survey data by age shows that, over 2004, households with a household head aged between 20 and 49 years were typically equity injectors (Figure 3 ). In contrast, older households were typically net withdrawers, with the size of the average net withdrawal increasing with age. This is consistent with the typical life-cycle pattern whereby younger households inject equity when they purchase their first home and trade up to more expensive housing in mid-life, before withdrawing equity when they sell property in their later years. Such a profile is also implied by the use of housing as an investment vehicle, given households will typically accumulate equity in their peak earning years. Indeed, of households that engaged in a property transaction and withdrew equity, just over half were 50 years of age or older, and they accounted for 61 per cent of the value of equity withdrawn

8 See Ellis et al (2003). 
by property transactors. In comparison, the same age bracket accounted for less than 40 per cent of total net injections. ${ }^{9}$

Figure 3

\section{Average net housing equity withdrawal by age}

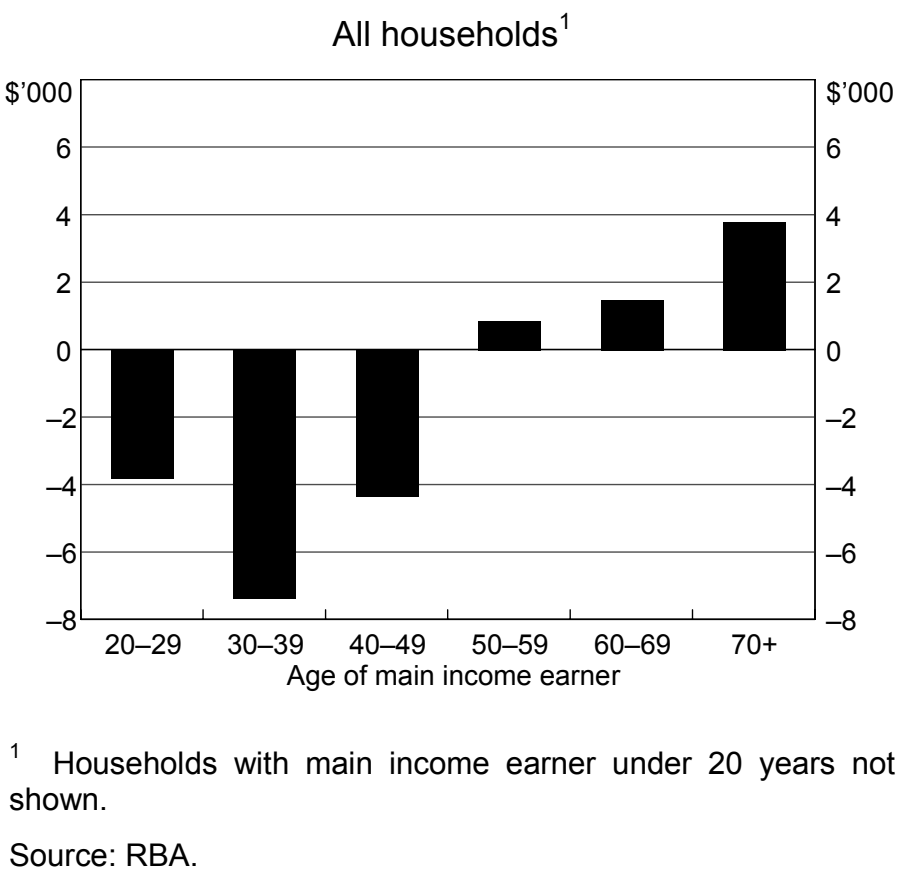

\section{Uses and sources of funds}

\subsection{Uses of funds for equity withdrawers}

The survey asked all households that withdrew equity (in net terms) over 2004 what they did with the funds withdrawn. Respondents were prompted with a number of possible answers, including using the funds for various types of consumption, the purchase of various assets, and the repayment of non-housing-related debt. Overall, the results suggest that, while a significant share (18 per cent) of the equity they withdrew over the year was used mainly for consumption, the bulk (58 per cent) was used mainly for asset accumulation, with an additional 8 per cent used mainly to pay down other debt (Table 5). ${ }^{10}$ Around 10 per cent of funds withdrawn were associated with a respondent that could not (or would not) say how the funds had been used.

9 Logit analysis also showed the life-cycle played an important role in influencing both the propensity and value of property transactors' withdrawals and injections. Age aside, there were few differences in the characteristics of households that injected without transacting and those that withdrew without transacting, although access to flexible mortgage features appeared to play some role in explaining household behaviour. See Schwartz, et al (2006) for details of the modelling undertaken.

10 This analysis apportions the full value of equity withdrawn by each household to the main use. An alternative approach is to split the withdrawn funds evenly between the identified uses when multiple uses were identified, and to assume that all households that did not report a use used the funds for consumption. This suggests that around 30 per cent of the funds withdrawn by all households withdrawing equity over 2004 were used for consumption. 
Table 5

Households withdrawing equity: main use of funds

Per cent

\begin{tabular}{|c|c|c|c|c|c|c|}
\hline & \multicolumn{2}{|c|}{ Non-transactors } & \multicolumn{2}{|c|}{ Property transactors } & \multicolumn{2}{|c|}{ All methods } \\
\hline & $\begin{array}{l}\text { Share of all } \\
\text { households }\end{array}$ & $\begin{array}{l}\text { Share of } \\
\text { value } \\
\text { withdrawn } \\
\text { by this } \\
\text { method }\end{array}$ & $\begin{array}{l}\text { Share of all } \\
\text { households }\end{array}$ & $\begin{array}{l}\text { Share of } \\
\text { value } \\
\text { withdrawn } \\
\text { by this } \\
\text { method }\end{array}$ & $\begin{array}{l}\text { Share of all } \\
\text { households }\end{array}$ & $\begin{array}{c}\text { Share of } \\
\text { total } \\
\text { value } \\
\text { withdrawn }\end{array}$ \\
\hline $\begin{array}{l}\text { Household } \\
\text { expenditure }\end{array}$ & 3.4 & 29.7 & 0.7 & 13.0 & 4.0 & 17.6 \\
\hline Of which: & & & & & & \\
\hline $\begin{array}{l}\text { Redecorations/ } \\
\text { durables etc }\end{array}$ & 1.5 & 13.0 & 0.3 & 6.9 & 1.8 & 8.6 \\
\hline Car & 1.3 & 12.0 & 0.2 & 3.6 & 1.5 & 5.9 \\
\hline Holiday & 0.5 & 2.9 & 0.2 & 1.3 & 0.6 & 1.7 \\
\hline Living expenses & 0.1 & 1.8 & 0.1 & 1.2 & 0.2 & 1.4 \\
\hline Asset accumulation & 1.6 & 41.0 & 2.3 & 65.2 & 3.9 & 58.5 \\
\hline Of which: & & & & & & \\
\hline Deposits & 0.6 & 18.6 & 1.3 & 38.6 & 1.9 & 33.0 \\
\hline Superannuation & 0.0 & 1.5 & 0.2 & 5.8 & 0.2 & 4.6 \\
\hline Household business & 0.3 & 4.9 & 0.1 & 2.0 & 0.5 & 2.8 \\
\hline Commercial property & 0.1 & 5.9 & 0.1 & 0.4 & 0.1 & 1.9 \\
\hline $\begin{array}{l}\text { Other non-property } \\
\text { investments }\end{array}$ & 0.5 & 10.2 & 0.6 & 18.4 & 1.2 & 16.1 \\
\hline Repay other debt & 0.7 & 8.3 & 0.4 & 7.4 & 1.2 & 7.7 \\
\hline Other & 0.6 & 4.6 & 0.4 & 7.1 & 1.0 & 6.4 \\
\hline Cannot say & 1.1 & 16.4 & 0.6 & 7.3 & 1.7 & 9.8 \\
\hline Total & 7.3 & 100.0 & 4.4 & 100.0 & 11.7 & 100.0 \\
\hline
\end{tabular}

Notes: Components may not sum due to rounding and calculations involve some imputation. Also, for each household, the full value of withdrawn equity has been apportioned to the specified main use of funds.

Source: RBA.

The largest category of accumulated assets was deposits, accounting for around one third of all withdrawn funds. Over a half of these deposits (by value) were from households that intended to use these funds to purchase or renovate residential property at a later date, with only 16 per cent (by value) intended to be left on deposit during 2005. Other forms of asset accumulation included investing in household businesses (3 per cent of withdrawn funds), commercial property ( 2 per cent), superannuation ( 5 per cent) and other non-property investments (16 per cent) such as equities.

The results also show that the use of funds varied considerably with the method of equity withdrawal. Non-transacting households that withdrew equity were much more likely to use the funds to finance consumption than were households that engaged in a property 
transaction and withdrew equity. Of non-transactors that withdrew equity and identified a specific use for the funds, over half indicated consumption spending, including home decorations, holidays, consumer durables and motor vehicles. A further 5 per cent of these households cited consumption as one, but not the main, use of the withdrawn equity.

In contrast, only about one fifth of transactors that withdrew equity and identified a specific use for the withdrawal indicated that the main use was to finance consumption. The more typical response was that the funds withdrawn were allocated to other assets. Households that withdrew larger amounts were more likely to specify a use of funds, probably reflecting the greater significance attached to larger expenditures.

\subsection{Alternative sources of funds for equity withdrawers}

Households that withdrew equity over 2004 were also asked what they would have done had they not been able to withdraw equity from their residential property. This provides some indication as to the role of housing equity in facilitating these transactions. Over half of those that withdrew equity during 2004 said that they would not have otherwise raised the funds; over a quarter said they would have applied for a loan or used their credit card; and around 10 per cent said they would have run down their savings (Table 6).

Table 6

Alternative source of funds if not withdrawn housing equity

Per cent of net withdrawers that would have:

\begin{tabular}{l|c|c|c}
\hline & Non-transactors & $\begin{array}{c}\text { Property } \\
\text { transactors }\end{array}$ & Total \\
\hline Not raised funds at all & 54.4 & 61.0 & 56.8 \\
Other secured loan & 19.5 & 11.9 & 16.7 \\
Run down savings & 9.9 & 10.5 & 10.1 \\
Credit card & 8.6 & 5.9 & 7.6 \\
Other unsecured loan & 8.7 & 2.4 & 6.3 \\
Other property-secured loan & 1.1 & 0.0 & 0.7 \\
Other sources & 6.6 & 8.3 & 7.2 \\
Cannot say & 1.1 & 3.6 & 2.0 \\
\hline
\end{tabular}

Notes: Columns sum to more than 100 per cent as some households provided multiple answers. Calculations involve some imputation.

Source: RBA.

Transactors were less likely than non-transactors to seek alternative sources of funds if they had not been able to access them via housing equity withdrawal, perhaps because transactors' decisions to withdraw or inject equity may often be secondary to their decisions to undertake property transactions. Those households using the funds for consumption were slightly more likely than other withdrawers to say that they would have accessed the funds from other sources if housing equity withdrawal had not been available to them.

The large proportion of non-transactor households that would not have otherwise raised funds suggests that their withdrawal of equity was in large part supported by the ease and relatively low cost of obtaining funds in this way. For transacting households the implications 
are less clear - raising funds may have been a by-product of their decision to transact for other reasons.

\subsection{Sources of funds for equity injectors}

Just as the use of withdrawn funds has implications for household spending, so too may the source of injected funds, since these funds could otherwise have been used for consumption purposes. For the 16 per cent of households that injected equity solely by making regular payments on their mortgage, income was presumably the main source of funds. Of the households making typically larger lump-sum injections, around half reported that they financed those injections primarily through drawing on savings and other assets, and around a quarter reported that they financed them from their regular income, with the remainder coming from various other sources (Table 7).

Table 7

Source of funds for lump-sum injectors

\begin{tabular}{l|c|c|c|c}
\hline & $\begin{array}{c}\text { Non- } \\
\text { transactors } \\
\text { (per cent) }\end{array}$ & $\begin{array}{c}\text { Property } \\
\text { transactors } \\
\text { (per cent) }\end{array}$ & $\begin{array}{c}\text { Total } \\
\text { (per cent) }\end{array}$ & $\begin{array}{c}\text { Median } \\
\text { (AS) }\end{array}$ \\
\hline Savings & 34.8 & 22.9 & 30.4 & 19000 \\
Income & 25.0 & 23.7 & 24.5 & 20000 \\
Sale of other assets & 15.0 & 30.4 & 20.6 & 73000 \\
Inheritance & 4.1 & 2.7 & 3.5 & 80000 \\
Loan from friends or family & 0.5 & 2.7 & 1.3 & - \\
Gift received & 1.0 & 2.7 & 1.6 & - \\
Other & 19.6 & 15.0 & 17.9 & 20900 \\
\hline
\end{tabular}

Note: Medians are not reported where sample size is very small.

Source: RBA.

\section{Aggregate implications of the survey}

Thus far, we have concentrated on the microeconomic results for 2004 arising from the survey. This section aims to draw some aggregate implications from these results. We consider factors contributing to movements in aggregate housing equity withdrawal in Australia over time, followed by the implications of housing equity withdrawal for key uses, such as consumption. As the survey was only for 2004, inference on earlier periods assumes that the findings are broadly representative of how equity was withdrawn and used in other years.

\subsection{Housing equity flows over time}

Section 3 shows that, over 2004, the largest aggregate flows of housing equity came from households transacting in the housing market. The typical housing transaction gave rise to net equity withdrawal, with vendors tending to have less debt remaining than was taken on by buyers, a pattern likely to be exacerbated by a period of rising house prices. 
These findings suggest that movements in turnover and house prices are important for movements in housing-secured credit and aggregate net housing equity withdrawal, a point borne out by the data. Figure 4 shows that the turnover rate of the national housing stock rose consistently over the mid to late 1990s, reaching a high level in 2002 and 2003 - a period in which housing equity withdrawal was also strong. Turnover then fell sharply through 2004 , at the same time as housing equity withdrawal declined. Similarly, nationwide house prices rose rapidly up to late 2003 , but have subsequently increased only modestly.

Figure 4

\section{Drivers of housing equity withdrawal}

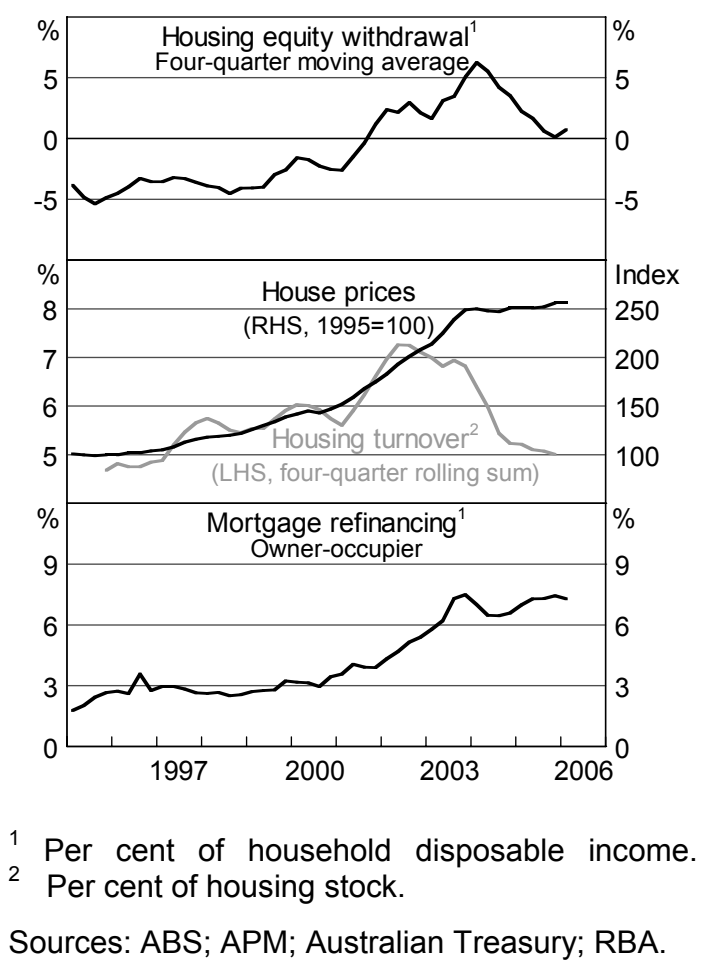

Another relevant consideration for housing equity flows is the activity of property investors. The share of housing loan approvals made to investors rose from around $1 / 3$ in 2000 to a peak of around 45 per cent in 2003, followed by a subsequent decline. This may have contributed to rising housing equity withdrawal up to 2003 because, according to the survey results, investors tend to purchase with relatively higher LVRs.

The survey results suggest that flows of housing equity due to non-transactors are of less importance. Nonetheless, partial data on these flows, where available, are also consistent with developments in aggregate housing equity withdrawal in recent years. The survey identifies mortgage refinancing as one of the main methods of withdrawing equity by nontransacting households. Australian Bureau of Statistics (ABS) data on refinancing of owneroccupier mortgages show rapid growth in loan refinancing during 2002 and 2003. In addition, borrowing through home-equity line-of-credit products increased by more than 30 per cent over 2003, before slowing. Movements over time in equity injection by non-transactors, however, are difficult to gauge, with various influences likely to have shaped any overall trend in principal repayments over recent years. These include ongoing growth in wealth and income, the increased share of interest-only loans and flexibility of many mortgage products. 


\subsection{Housing equity flows and economic activity}

The survey results suggest that movements in housing equity withdrawal need not be associated with large swings in consumption. To the extent that property transactions are a key driver of movements in net housing equity flows, and the bulk of equity extracted from transactions appears to be used to acquire non-housing assets, changes in housing equity flows are likely to be only partly reflected in changes in consumption. Nevertheless, it remains likely that the trend rise in equity withdrawal evident in Australia for much of the past 10 to 15 years has been one of the factors supporting strong growth in consumption over that period.

For 2004, the results suggest that around 18 per cent of the aggregate equity withdrawn by net withdrawers was used for consumption, which represents around $2 \frac{1}{2}$ per cent of the level of aggregate household consumption. However, this estimate may understate the amount of gross withdrawals used for consumption (see footnote 9).

The static nature of the survey means that it is not possible to assess contributions to growth from the survey data alone. Nonetheless, it seems likely that the strong growth in housing equity withdrawal over 2001 to 2003 contributed to very strong growth in consumption relative to income (and a corresponding decline in the saving rate) over that period. Trends in aggregate financial variables over that period are also consistent with the survey findings on uses of withdrawn equity. Flows into financial assets were above average, and personal credit growth was well below that of housing credit, consistent with households withdrawing housing equity as a substitute for other debts. These trends have subsequently abated.

Another channel through which swings in household borrowing affect economic activity is spending on renovations. Borrowing to finance this form of spending does not necessarily lead to a withdrawal of equity, if the borrowed funds are used solely to increase the value of the household sector's housing assets. Nevertheless, the effect on overall activity can be significant. Over recent years, annual spending on renovations has averaged around $4 \frac{1}{2}$ per cent of household disposable income, up from an average of around $3 \frac{1}{2}$ per cent between 1990 and 1998. The survey data suggest that, in many cases, renovations have been partly funded by drawing down on the equity built up as a result of the large house prices increases the mid 1990s. Around 11 per cent of surveyed households spent money on renovations in 2004 , with the median amount spent on the main home equal to $A \$ 14000$. Around 40 per cent of these households used housing debt to at least partly finance their renovation expenditure, with debt finance being used more often for larger renovations.

\section{Conclusion}

The survey results provide a wide range of information relating to housing equity flows. In addition to being the first survey of its kind in Australia, the comprehensive approach extends the more narrowly focused surveys conducted internationally on this topic. This survey captured flows of both housing equity withdrawal and injection by all households including flows associated with deceased estates, non-transaction-related debt repayments, and nondebt-financed renovations. Another innovation is information gathered on the features of each household's mortgage, to help gauge the importance of new financial products to housing equity flows.

The results of the survey suggest that any aggregate series for net housing equity withdrawal or injection masks large aggregate withdrawals and injections by households. Over 2004, 30 per cent of households made net equity injections, while 12 per cent made net equity withdrawals. The values injected were, however, typically much less than those withdrawn. The most common methods of withdrawing or injecting housing equity were through altering debt levels on already-owned property holdings. Though fewer in number, withdrawals and 
injections of housing equity associated with property transactions were typically significantly larger in value, accounting for the bulk of the value of housing equity flows.

The survey data show a significant life-cycle influence on housing equity flows, particularly among property transactors. Over 2004, the bulk of equity withdrawal was undertaken by older households, while younger households typically injected through deposits for property purchase or mortgage repayments. To our knowledge this intuitive result has not previously been demonstrated empirically.

The use of equity withdrawn tended to vary with the method by which it was accessed. Withdrawals associated with property transactions were used significantly more for accumulation of non-property assets than consumption, a preference less evident for nontransaction-based withdrawals. Overall, around two thirds of equity withdrawn by net withdrawer households in 2004 was mainly invested in other assets or used to pay down other loans.

These results have some potentially important aggregate implications. Swings in housing equity withdrawal are likely to be heavily influenced by turnover in the property market, given the importance of such transactions to gross flows and the observation that the typical property transaction results in net equity withdrawal. This effect is likely to be amplified following a period of sustained house price growth, and is consistent with the large increase in aggregate housing equity withdrawal in Australia between 2001 and 2003, along with its subsequent decline. Secondly, the survey results also suggest that a significant number of households have used refinancing opportunities over recent years to increase the size of their debts, for purposes including consumption and renovation. Thirdly, only a relatively small portion of overall equity withdrawn from the housing stock in 2004 was used for consumption. 
Appendix A:

Defining equity injectors and withdrawers

\section{Table A1}

Classification of equity injectors and withdrawers

\begin{tabular}{|c|c|c|}
\hline Component & Calculation & Notes \\
\hline $\begin{array}{l}\text { Change in } \\
\text { housing debt }\end{array}$ & $\begin{array}{l}\text { Outstanding housing debt } \\
\text { at end } 2004 \\
\text { minus } \\
\text { Outstanding housing debt } \\
\text { at end } 2003\end{array}$ & $\begin{array}{l}\text { Households with offset accounts separately } \\
\text { provided information on offset account balances } \\
\text { at end } 2003 \text { and end } 2004 \text {, which were used to } \\
\text { obtain net loan balances. }\end{array}$ \\
\hline $\begin{array}{l}\text { Change in } \\
\text { housing equity } \\
\text { from } \\
\text { transactions }\end{array}$ & $\begin{array}{l}\text { Value of properties } \\
\text { purchased (including } \\
\text { transfer costs) over } 2004 \\
\text { minus } \\
\text { Value of properties sold } \\
\text { (net of transfer costs) } \\
\text { minus } \\
\text { Value of funds obtained } \\
\text { through sale of inherited } \\
\text { property. }\end{array}$ & $\begin{array}{l}\text { Households provided information on the value of } \\
\text { residential property purchases and sales, } \\
\text { including funds flowing from the sale of inherited } \\
\text { property, either by the household selling the } \\
\text { property directly, or receipt of funds arising from } \\
\text { trustee sale. This ensured that equity withdrawals } \\
\text { arising from death were captured. } \\
\text { The value of any properties inherited and retained } \\
\text { during the year were not counted as an injection, } \\
\text { largely because such transfers did not involve } \\
\text { spending by the inheriting household. Transfer } \\
\text { costs associated with the acquisition were, } \\
\text { however, counted as housing spending. }\end{array}$ \\
\hline Renovations & $\begin{array}{l}\text { Amount spent on } \\
\text { renovations }\end{array}$ & $\begin{array}{l}\text { Attempts were made throughout the survey to } \\
\text { ensure that renovation spending captured only } \\
\text { alterations of a structural nature in accordance } \\
\text { with national accounts definitions; that is, not } \\
\text { redecorations and maintenance such as } \\
\text { repainting, for example. }\end{array}$ \\
\hline
\end{tabular}

Note: Housing equity withdrawal is calculated as change in housing debt, minus change in housing equity from transactions, minus renovations.

Source: RBA. 


\section{References}

Benito A and J Power (2004): "Housing Equity and Consumption: Insights from the Survey of English Housing", Bank of England Quarterly Bulletin, Autumn, pp 302-309.

Canner G, K Dynan and W Passmore (2002): "Mortgage Refinancing in 2001 and Early 2002", Federal Reserve Bulletin, December, pp 469-481.

Davey M and F Earley (2001): Mortgage Equity Withdrawal, Council of Mortgage Lenders, London, available at <http//:www.cml.org.uk>.

de Nederlandsche Bank (2000): "Survey among Dutch Mortgage-holders on the Use of Mortgage Credit", Nederlandsche Bank Quarterly Bulletin, June, pp 31-43.

Ellis L, J Lawson and L Roberts-Thomson (2003): "Housing Leverage in Australia", Reserve Bank of Australia Research Discussion Paper No 2003-09.

Reserve Bank of Australia (2002a): "Recent Developments in Housing: Prices, Finance and Investor Attitudes", Reserve Bank of Australia Bulletin, July 2002, pp 1-6.

(2002b): "Innovations in the Provision of Finance for Investor Housing", Reserve Bank of Australia Bulletin, December, pp 1-5.

(2005): "Survey on Housing Equity Withdrawal and Injection", Reserve Bank of Australia Bulletin, October, pp 1-12.

Schwartz C, T Hampton, C Lewis and D Norman (2006): "A Survey of Housing Equity Withdrawal and Injection in Australia", Reserve Bank of Australia Research Discussion Paper No 2006-08.

van Els P, W van den End and M van Rooij (2005): "Financial Behaviour of Dutch Households: Analysis of the DNB Household Survey 2003", in Investigating the Relationship between the Financial and Real Economy, BIS paper no.22 (2005). 